\title{
Enabling Inclusive Development Concept in Marginalized Settlement Community (Case Study: Kampung Jodipan, Kota Malang)
}

\author{
Merisa Kurniasari, Arina Hayati and Purwanita Setijanti \\ Department of Architecture, Institut Teknologi Sepuluh Nopember, Surabaya \\ e-mail: arina_h@arch.its.ac.id
}

\begin{abstract}
The era of democratization requires city leaders to change the development paradigm to be inclusive. This is stated in goal number 11 of the SDGs document, "making cities and human settlements inclusive, safe, resilient, and sustainable", so this study tries to look at the concept of inclusiveness in the scope of settlements, especially in marginal settlements. This study takes place in marginal settlements in the Brantas watershed as Kampung Jodipan which was once a slum settlement but now has been transformed into a Kampung tourism. This openness applies the principle of inclusiveness of the Kampung Jodipan. The data of this research were analyzed with descriptive statistics using Factor Analysis and Cross Tabulation, then the data was validated using triangulation analysis. This study aims to highlight the experience of Kampung Jodipan as a marginal settlement that has succeeded in improving Kampung. It was found that the inclusiveness dimensions in Kampung Jodipan were social inclusion and physical inclusion. Socially, the embodiment of the inclusiveness can be seen through the trust of the community and involving the residents in various activities. Meanwhile, the concept of spatial inclusiveness is manifested with the inclusion of basic infrastructure as a means of meeting the daily needs of citizens.
\end{abstract}

Keywords-Inclusive Development, Inclusive Cities, Inclusive Settlement, Marginalized.

\section{INTRODUCTION}

$\mathrm{U}$ NITED Nations in 2015 made the Sustainable Development Goals (SDGs) document, in one of its articles mentions "make cities and human settlements inclusive, safe, resilient, and sustainable". The intended target is to provide public spaces that are safe, easily accessible and green, especially for women and children, the elderly and the disabled. The inclusive concept according to the World Bank (2015) is seen from urban development, including spatial inclusiveness, social, and economic [1]. The spatial, social and economic dimensions are considered to be interrelated factors and have a big influence on poverty alleviation and marginalization. In the 2016 New Urban Agenda Document, there is a commitment to stimulate the provision of decent and safe housing, affordable and easily accessible to people with diverse incomes, and to consider the socio-economic and cultural integration of marginalized communities to prevent segregation. In addition, the commitment of "cities for all" in the New Urban Agenda document, referring to the use of the same city and settlement, seeks to promote inclusiveness and ensure that all residents, present or future generations, without

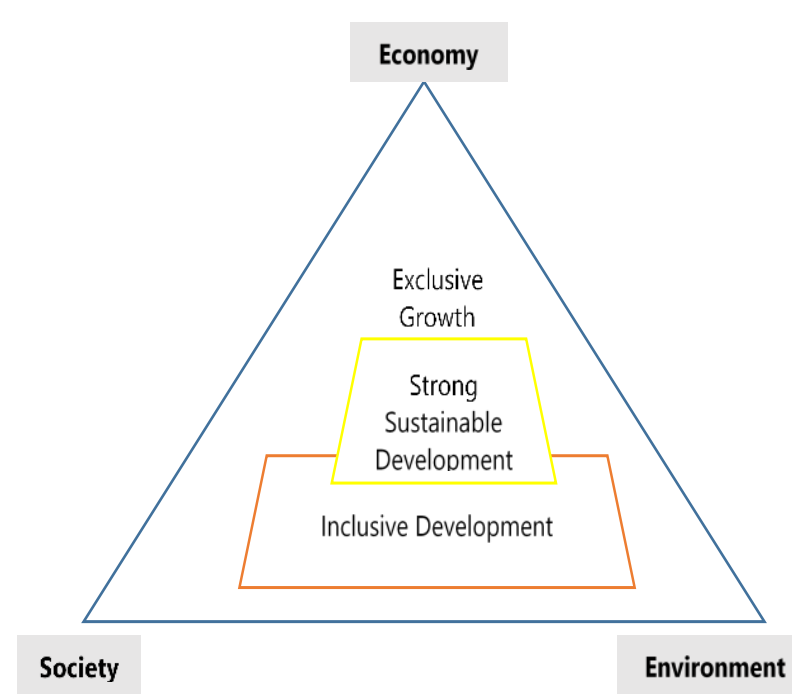

Figure 1. The Relationship between Inclusive Development and Sustainable Development.

discrimination in any form, can inhabit the city safely, healthy, easily accessible, affordable and sustainable with the support of the central government and local government.

There is not much research on inclusive development in the sphere of settlements. Whereas the marginal group which is one of the focus of handling the inclusive development is sheltered in a settlement as one of the main needs of life. For this reason, this research tries to look at the concepts of inclusive development and inclusive cities that are applied to the margins of marginal settlements. Marginal settlements have slum characteristics and are in areas that should not be occupied by developed land such as in the River Basin. This research takes place in marginal settlements in the Brantas River Basin namely Kampung Jodipan, Malang City which is famous as a slum settlement but now has changed its face to become a tourist attraction and has succeeded in attracting tourists so that it can be said that Kampung Jodipan as marginal settlements opening up to the outside world. This openness indicates the concept of inclusive city which is applied to the development of Kapung Jodipan. This then raises the question of what is the concept of inclusive cities within the scope of settlements applied in Kampung Jodipan, which will be examined in this research.

The purpose of this research is to examine the concepts of inclusive development and inclusive cities obtained from the literature review. This research wanted to find out the forms 
The $6^{\text {th }}$ International Seminar on Science and Technology (ISST) 2020

July $25^{\text {th }}, 2020$, Institut Teknologi Sepuluh Nopember, Surabaya, Indonesia

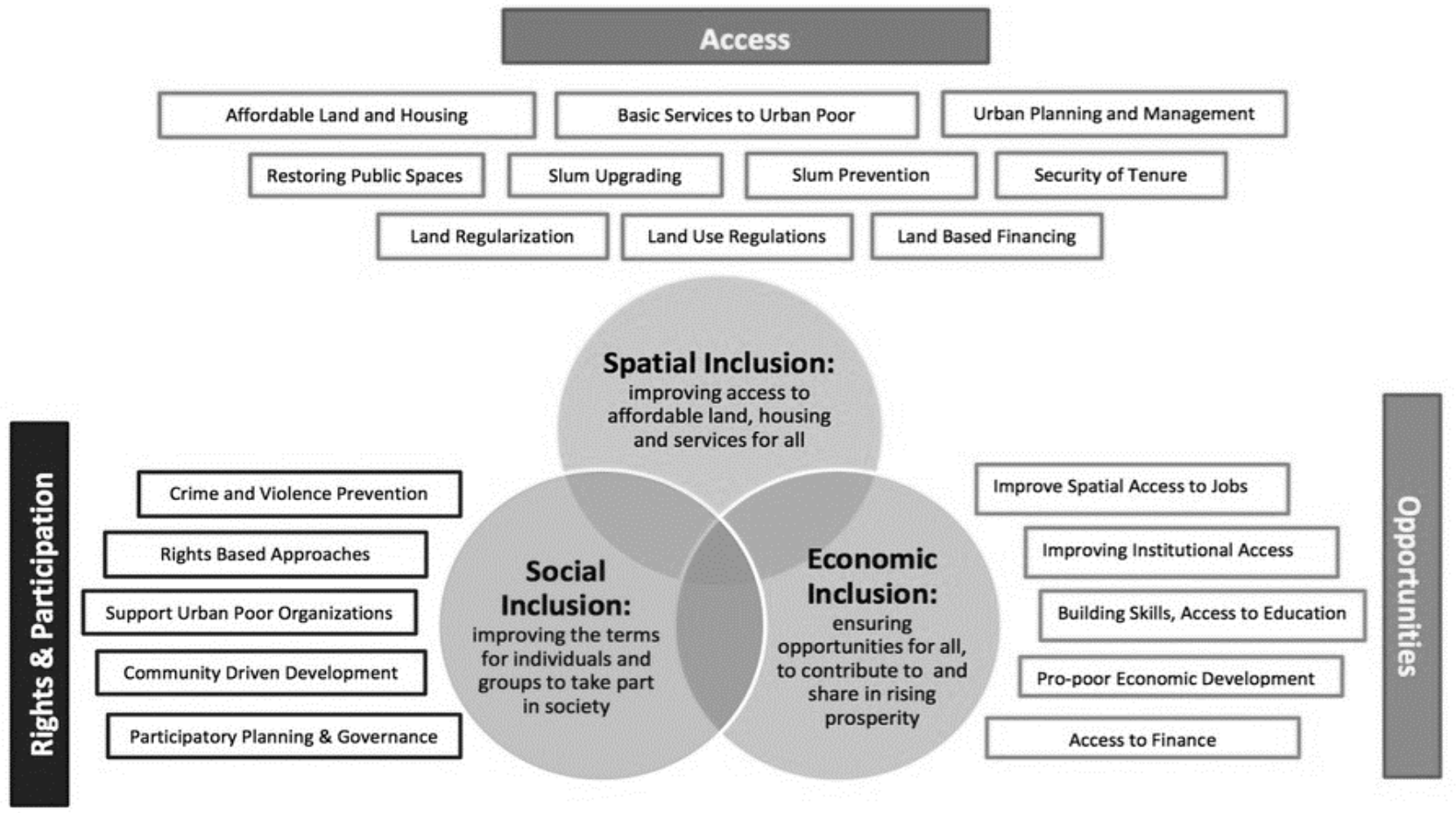

Figure 2. Inclusive cities approach.

of inclusiveness that exist in Kampung Jodipan based on indications of inclusivity, so it is necessary to analyze the factors of inclusivity in settlements that have an influence in Kampung Jodipan.

\section{LITERATURE REVIEW}

\section{A. Applying Inclusive Development to Sustainable Development Goals}

Gupta and Vegelin (2016) group the goals in the Sustainable Development Goals into the principle of inclusiveness [2]. The principle of inclusive development contains the objectives of the concept of sustainable development. The principle of social inclusion contains 11 goals out of 17 SDGs objectives which focus on the most marginalized issues. However, the commitment to overcome ecological inclusiveness in the SDGs document is lower. Although 11 goals address ecological problems, most focus only on the transfer of technology and scientific solutions and not enough on the need to redefine the concept of growth based on the limited availability of ecospace and the need to improve human well-being. While relational politics in the SDGs document mentions global inequality, and the need for taxes for the rich and reforming global institutions to create an equal playing field, relational politics in inclusive development put more responsibility on the private sector and focus on multi-scalar decision-making bodies that represent the potential for important change. relationship between inclusive and sustainable development can see at Figure 1.

\section{B. Inclusive Development Concept}

An inclusive development approach is needed to balance the dominance of a region's growth approach, especially in the context of the global recession. According to Gupta and
Vegelin (2016), there are three principles of inclusiveness, including social inclusiveness, ecological inclusiveness, and relational inclusiveness [2].

\section{1) Social Inclusiveness}

Social inclusiveness is rooted in human rights, inequality, redistribution, rural development, rights and the concept of capability and has been stated in the Millennium Development Goals. Social inclusiveness can be done by encouraging participation, adopting the principles of equity, capacity building, technology transfer, and financial support. At the regional level, social inclusiveness plays a role in the issue of conflict-prone countries and equitable distribution of resources across borders. At the national level, taking into account marginalized sectors, places and communities. At the local level, it takes more into account for certain individuals and groups. Social inclusiveness aims to empower the poor through investment in social capital and increase opportunities for participation that also takes into account age, sex, caste, income, assets and opportunities for employment. It aims to reduce risk exposure such as natural disasters and civil conflicts which exacerbates vulnerability.

\section{2) Ecological Inclusiveness}

The relationship between environmental problems and the marginalized, arises from three different strands. First, the poor depend on local ecosystems for their survival. Second, the vulnerability argument focuses on how the vulnerability of the poor can be exacerbated by the impacts of climate change and thus demands increased capacity and adaptive resilience. Third, large acceleration in demand for limited land, water and other resources can lead to a scramble for ecospace or large-scale transfers from local communities to government, large companies and the private sector by changing the rules of access to these resources which can further exacerbate vulnerability poor society. 


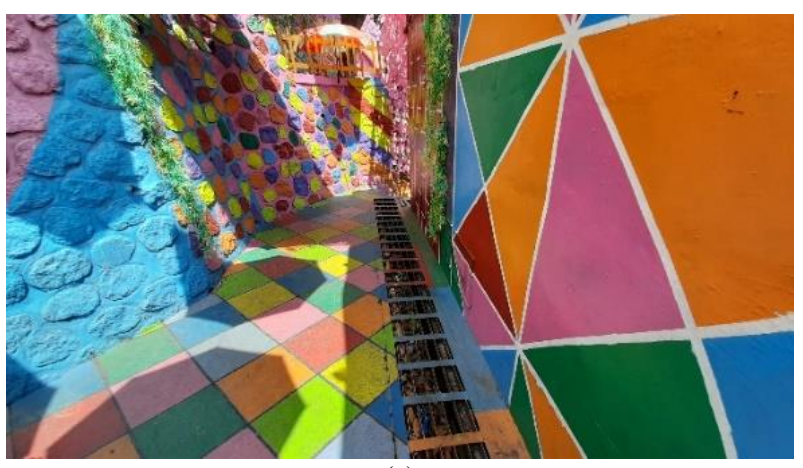

(a)

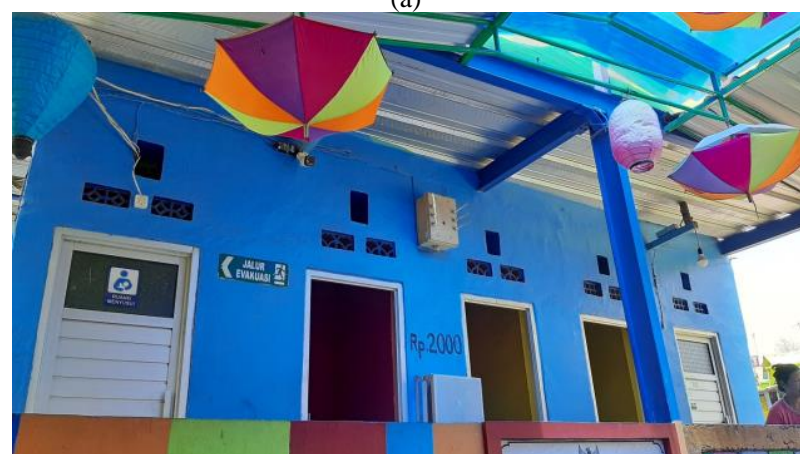

(b)

Figure 3. (a) Physical Condition of Drainage Channels; (b) Shared Bathroom in Kampung Jodipan.

\section{3) Relational Inclusiveness}

Relational inclusiveness recognizes that poverty and ecological degradation are often the result of increasing inequality in society as well as political processes. Social inequality refers to differences in income, wealth, opportunities and access between the rich and the poor. The rich become richer through the accumulation of historical assets that are not taxed, capital market exploitation (where investors are saved by taxpayers at the expense of the homeowner), and the development of intellectual property rights that protect patents among others.

\section{Inclusive Cities}

The inclusive cities project overseen by the World Bank mentioned three important factors for building an inclusive city: First, spatial inclusion (physical) inclusion which includes the availability of basic daily infrastructure in the form of livable housing, clean water and sanitation. Second, social inclusion. An inclusive city must guarantee equality of rights and participation of all people, including those who are most marginalized. Their exclusion was proven to cause inequality and social unrest in various cities. Third, economic inclusion or economic inclusion. An inclusive city must be able to create jobs and opportunities for all city residents to enjoy the fruits of economic growth. Inclusive cities approach can see at Figure 2.

\section{RESEARCH METHOD}

This study uses a post-positivism approach, looking at the role of subjects that determine the presence or absence of reality. The post-positivism paradigm assumes that each phenomenon is part of a unified whole that can be determined or explained only by using a set of factors [3].

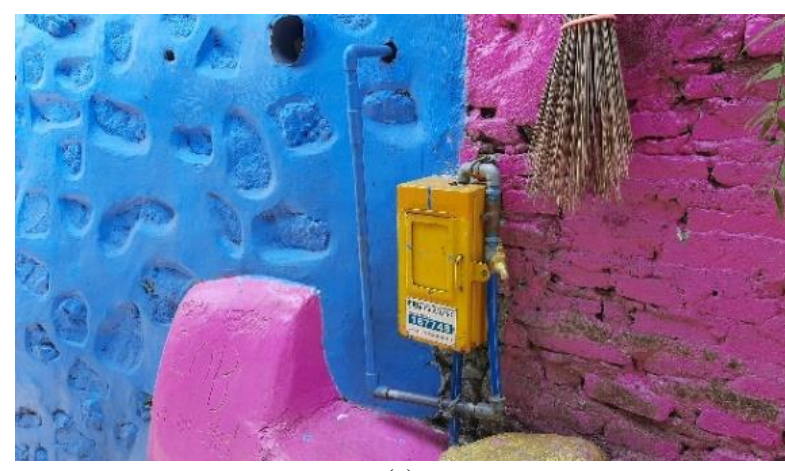

(a)

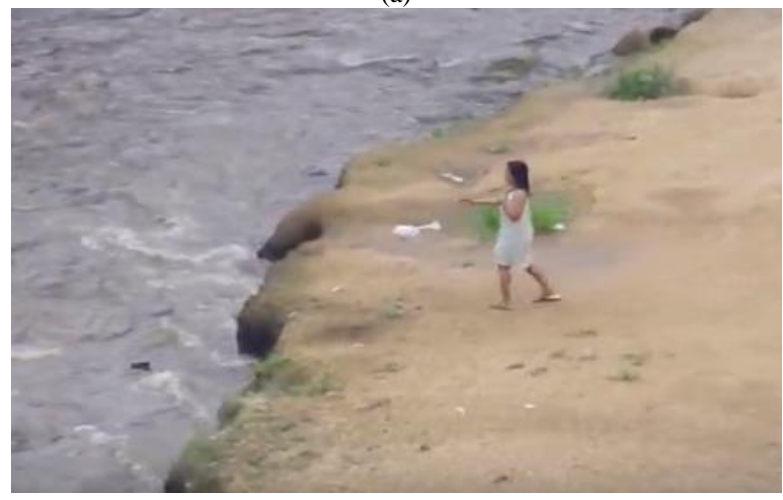

(b)

Figure 4. (a) Water Pipelines; (b) Garbage dumped into the river in Kampung Jodipan.

This research is using a phenomenological approach because the problem is social experience in the form of the phenomenon of slums. Phenomenology in this research is used to seek understanding of complex life experiences from the point of view of the people who live it. The viewpoint relates to the handling of slums in Kampung Jodipan which could become a Kampung tourism, researchers observed directly the embodiment of handling slum and also conducted interviews with respondents such as ticket entry guards and residents selling in the Kampung Jodipan area. Data from the questionnaire were analyzed statistically and linked to local community demographic data which was also asked in the questionnaire, so that researchers could see the relationship between the two. Data were analyzed with descriptive statistics using Factor Analysis and Cross Tabulation, then the data was validated using triangulation analysis.

\section{PHYSICAL CHARACTERISTIC OF KAMPUNG JODIPAN}

Starting from university students who had a community titled Guyspro who felt that the slums of Kampung Jodipan were clearly visible from the Brantas river bridge and were not pleasing to the eye. After exploring the location study area several times, the idea emerged to make Kampung Jodipan like a settlement in Rio De Jeneiro in the Brazilian state armed with cooperation with paint companies. The innovation to the Kampung Jodipan that made this settlement improve itself, including its inhabitants, was by coloring the houses of people who then fade the impression of slums. Based on in-depth interviews with informants in Kampung Jodipan, this is what later opened the views of the 
Table 1.

Comparison of research factors before and after factors analysis

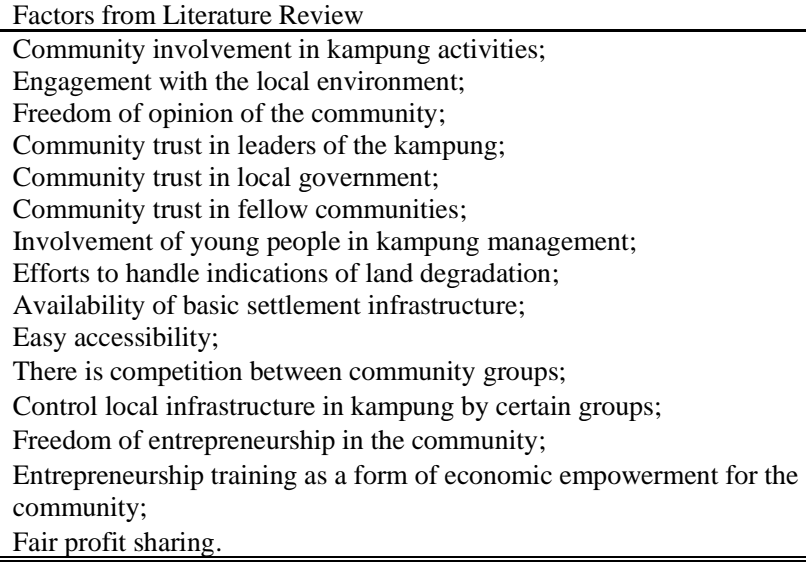

local community to be more serious in fixing their settlement.The results of the observation about physical characteristic Kampung Jodipan are:

\section{A. Drainage and Domestic Wastewater Management Conditions}

Provision of adequate drainage networks is needed in each environment and even slums. Based on the provisions, the provision of drainage is not only limited to the construction of the channel, but there is a minimum quality that needs to be met so that the function of the channel can work optimally. In Kampung Jodipan, land for drainage is owned by residents / the public and self-help and the value of mutual cooperation is quite good but the dimensions of drainage are small so that it cannot accommodate rainwater. Besides that the drainage channel is not functioning properly, it can be seen that the channel is filled with dry leaves. In Kampung Jodipan, the community has access to family toilets / shared latrines according to technical requirements (has a goose neck toilet that is connected to a septic tank) with a separate household sewage and environmental drainage. Physical condition of drainage and share bathroom condition can be seen at Figure 3 .

\section{B. Water Supply Condition and Waste Management Condition}

In Kampung Jodipan, $72 \%$ of the community is served with drinking water, bathing, and washing facilities (piping or non-protected pipelines are feasible) and $94 \%$ of the community has met the needs of drinking water, bathing, washing (minimum 60 liters / person / day). Meanwhile, the percentage of household domestic waste transported to the TPA / TPS at least every two weeks is $72 \%$, including the lowest of other RWs that have obtained a percentage of $100 \%$. Water pipelines at Kampung Jodipan can be seen at Figure 4(a) and garbage in the river in Jodipan can be seen at Figure 4(b).

\section{THE EFFECT OF INCLUSIVITY DIMENSIONS}

From the results of the literature study, found that inclusiveness consists of dimensions of social inclusion, physical inclusion, relational inclusion, and economic inclusion. Based on the explanation of these dimensions then the inclusiveness factors of each dimension are produced. To be analyzed using factor analysis, these factors are separated in advance from their dimensions to find out which is the most influential. These factors include:

1. Community involvement in kampung activities;

2. Engagement with the local environment;

3. Freedom of opinion of the community;

4. Community trust in leaders of the kampung;

5. Community trust in local government;

6. Community trust in fellow communities;

7. Involvement of young people in kampung management;

8. Efforts to handle indications of land degradation;

9. Availability of basic settlement infrastructure;

10. Easy accessibility;

11. There is competition between community groups;

12. Control local infrastructure in kampung by certain groups;

13. Freedom of entrepreneurship in the community;

14. Entrepreneurship training as a form of economic empowerment for the community;

15. Fair profit sharing.

From these 15 factors, based on factor analysis, it was found that 6 research factors had no influence in Kampung Jodipan, these factors included competition among community groups, and control of local infrastructure in kampung by certain groups included in relational inclusion. Factors of freedom of entrepreneurship in the community, entrepreneurship training as a form of economic empowerment to the community, and the fair distribution of benefits included in economic inclusion and there is also a factor of social inclusion, namely community trust in local government.

There is 1 factor of Social Inclusion is reduced, the community's trust in local government. This happened because the people of Kampung Jodipan do not have full trust in the local government. According to the residents, it because the local government before Kampung Jodipan changed to what it is today it seldom pays further attention to the state of Kampung Jodipan. From the concept of inclusive development put forward by Sultana in Kooy (2018) [4], before becoming a kampung tourism, residents 
of Kampung Jodipan experienced exceptions from development, marginalization, and inequality so it can be said that the local government of Malang had not yet taken a role in the concept of inclusive development.

Other reduced factors are factors of Relational Inclusion, namely Competition among community groups, and Control of local infrastructure in kampung by certain groups. According to residents there is competition from other kampung that apply a similar concept, but never cause a bad impact for each group because the competition is to attract tourists. Furthermore, it was explained by the residents that there was no special interest from the internal residents of Kampung Jodipan to be able to control or get more profit from other residents. The management of the Kampung Jodipan tourism itself went well, seen from the response of residents who said that from the results of the tourism, residents who needed help would be assisted in the form of money or basic needs. From the results of tourism, residents also can afford to pay school entrance fees for their children.

The factor of Competition and Control of local infrastructure in kampung by certain groups for Relational Inclusion becomes a factor that does not have the effect of the results analyzed using factor analysis, this matter after being traced and asked back to the residents of Kampung Jodipan stated that some residents did feel that there was control of infrastructure facilities by a group in Kampung Jodipan. Parking facilities in Kampung Jodipan are controlled by certain groups outside Kampung Jodipan. This needs to be resolved between relevant stakeholders.

According to Gupta and Vegelin, relational inclusion is closely related to the privatization of public facilities, if it occurs in an area it can be said that the region is not relational inclusive then action needs to be taken to pursue the public interest. The relational approach requires policies that deal with all actors including those that conflict with policies that deal with empowering marginal communities. This is in line with the 10th SDGs Goal, which is trying to reduce inequality; also the 12 th goal of controlling private ownership; and the 16th goal is to promote a peaceful and inclusive society, and get access to justice.

Three factors of economic inclusion are included in the reduced factor, namely freedom of entrepreneurship in the community, entrepreneurship training as a form of economic empowerment to the community, and equitable distribution of profits. These factors are reduced because the economic activities in Kampung Jodipan are still unable to develop. Residents claimed to be free to enter into entrepreneurship and get training, but the trading businesses that have been run are not getting satisfactory results because the location is not strategic or does not get enough profit as capital to buy materials. While the fair profit sharing factor is a reduced factor because some residents feel the financial statements containing income and expenditure of the kampung tourism are still not fully open.

According to the Asian Development Bank (2017) income and social aspects of poverty can be overcome by building financial assets and social capital of the urban poor through investments to generate income (microfinance and small and medium business development), social protection, and education. ADB's social protection strategy policies and programs aim to help people in marginal areas break the cycle of poverty, increase growth through investments in human resources, increase productivity, and reduce their vulnerability to risk. So it is important to do socialization and also training so that marginalized communities are also able to compete globally [5]. The comparison of research factors before and after factors analysis listed in Table 1.

\section{THE EFFECT OF DEMOGRAPHIC FACTORS}

World Bank (2015) concerning inclusive cities that emphasizes attention to needs based on community conditions, such as age (children, young people, the elderly), gender, and differently abled groups. Therefore this research looks at respondents based on age, gender, occupation, income, education, and length of stay in marginal settlements. From the discussion using triangulation analysis, socio-demographic factors have been found that affect the inclusiveness in Kampung Jodipan. The conclusion is that the Age factor is the factor with the highest number of choices, followed by the factor of Length of stay, Income factor, Occupation factor, Educational factor, and Gender factor.

1. Age. The influence of senior citizens (46-65 years old) is still quite strong in Kampung Jodipan both in meetings and in routine annual activities, active as a participant of the meeting and decision maker. Citizens' trust towards senior citizens is still quite large. The residents of Kampung Jodipan admitted that they tend to choose elderly residents as administrators.

2. Length of Stay. Residents tend to elect residents who have lived for more than 50 years in Kampung Jodipan as a speaker board when holding discussions with stakeholders related to any discussion such as for example discussion of relocation to flats. Residents who have lived more than 50 years are considered to have more experience and are well aware of the ins and outs of Kampung Jodipan.

3. Income. In Kampung Jodipan not many residents have permanent jobs. The maximum average income is 3.5 million rupiah per month. However, residents continue to help each other if there is trouble and need help. Residents also continue to actively participate in activities in Kampung Jodipan, especially if there is an event on economic empowerment.

4. Occupation. Many residents of Kampung Jodipan work as traders and work odd jobs. The people of Kampung Jodipan are slowly starting to depend their lives on tourism activities, if tourism activities are closed, it will behard for them to get income.

5. Education. Senior citizens on average have elementary and junior high school education. While many young people aged 12-45 years old have graduated from high school and have high education. Even so in managing the kampung residents prefer those who have diverse experiences. This makes young people in Kampung Jodipan feel a little marginalized because the opinions put forward are accommodated but always eliminated. 
The $6^{\text {th }}$ International Seminar on Science and Technology (ISST) 2020

July $25^{\text {th }}, 2020$, Institut Teknologi Sepuluh Nopember, Surabaya, Indonesia

6. Gender. There are no gender issues in Kampung Jodipan. Male and female citizens fully help each other and share the proportion of tasks in the kampung tourism fairly and equally. There are no restrictions for women citizens to do activities in this residential area. The involvement of women citizens in the kampung tourism is as a ticket guard for the tourist and a glass bridge guard.

\section{REFERENCES}

[1] Word Bank. 2015. World Inclusive Cities Approach Paper http://documents.worldbank.org/curated/en/402451468169453117/W orld-Inclusive-cities-approach-paper.

[2] Gupta and Vegelin. 2016. Sustainable Development Goals and Inclusive Development. Int Environ Agreements (2016) 16:433-448 DOI 10.1007/s10784-016-9323-z.
[3] Groat and Wang. 2013. Architectural Research Method. Canada: John Wiley \& Sons.

[4] Kooy, Walter, and Prabaharyaka. 2018. Inclusive Development of Urban Water Services in Jakarta: The role of groundwater. Journal of Habitat International volume 73, March 2018, Pages 109-118.

[5] Asian Development Bank. 2017. Enabling Inclusive Cities: Tool Kit for Inclusive Urban Development. 2017 Asian Development Bank.

[6] UN-HABITAT. 2007. Inclusive and Sustainable Urban Planning: A Guide for Municipalities. Volume 1: An Introduction to Urban Strategic Planning.

[7] United Nation. 2016. Habitat III-New Urban Agenda. Habitat III Secretariat United Nation (UN).

[8] Warsilah, Henny. 2017. Inclusive Development and Social Policy in the City of Solo, Central Java. Jakarta: Yayasan Pustaka Obor Indonesia.

[9] Asian Development Bank. 2011. Urban Development Series: Inclusive Cities. Metro Manila: Asian Development Bank.

[10] Gupta, J. dkk. (2015). Towards an elaborated theory of inclusive development. European Journal of Development Research, 27 (4) https://openknowledge.worldbank.org/handle/10986/16195 